\title{
CRONOTOPUL ORAȘULUI CHIȘINĂU ÎN RAPORT CU APARIȚIA ȘI EVOLUȚIA PERSONAJELOR ÎN PROZA ROMÂNEASCĂ
}

\author{
SiLVIa COTORCEA \\ Universitatea de Stat din Moldova
}

\begin{abstract}
Rezumat. În studiul de față încercăm să explicăm relația și influența reciprocă dintre cronotopul literar al orașului Chișinău și personajele din proza românească. Astfel, analiza sincronică și diacronică a eroilor din textul epic demonstrează existența unui raport direct proporțional dintre timp, spațiu și personaj. Or, aceste trei componente de bază ale subiectului operei literare se prezintă ca un sistem menit să fundamenteze creația autorului.De asemenea, evidențiem legătura de cauzăefect între apariția, evoluția personajelor și timpul, spațiul literar al urbei - viața și activitatea eroilor se aliniază lângă noțiunea de Homo Moldovanus Sovietic. În acest sens, interrelația cronotop-personaj presupune o abordare interdisciplinară și complexă, menită să ilustreze momentele subiectului textului literar.
\end{abstract}

Cuvinte-cheie: cronotop, personaj, Homo Moldovanus Sovietic, Chișinău, literatură, relație de interdependență.

\begin{abstract}
In this study we try to explain the relationship and the mutual influence between the literary chronotope of city Chișinău and the characters from romanian prose. Thus, the synchronous and diachronic analysis of the heroes in the epic text demonstrates the existence of a directly proportional relationship between time, space and character. However, these three basic components of the subject of the literary work are presented as a system meant to substantiate the author"s creation. We also highlight the cause-effect relationship between the appearance, the evolution of the characters and the literary time, space of the city - the life and activity of the heroes are aligned near the precept Homo Moldovanus Sovietic. In this sense, the chronotope - character interrelation presupposes an interdisciplinary and complex approach, meant to illustrate the moments of the subject of the literary text.

Keywords: chronotope, character, Homo Moldovanus Sovietic, Chișinău, literature, interdependence relationship.
\end{abstract}

În dialogismul lui Bahtin, termenul de cronotop reprezintă relațiile temporale și spațiale valorificate artistic în literatură. Savantul rus împrumută acest concept din fizică, mai exact din teoria relativităţii a lui A. Einstein, pentru a numi procedeul responsabil de crearea structurii particulare a unui univers artistic romanesc.

Conceput ca instrument de analiză în cadrul disciplinei de poetică istoric $\breve{a}$, termenul este utilizat de Bahtin pentru a desemna marile unități ale 
imaginaţiei romanești. Spre deosebire de poeticienii formalismului rus, el consideră poetica istorică ca o disciplină care trebuie să înțeleagă nu „,cum este făcută opera", ci care este locul acesteia într-o anumită tipologie de sistem semiotic. În locul unui catalog de procedee care, potrivit formaliștilor alcătuiesc povestirea, savantul introduce o tipologie a universurilor literare, constituite de istorie în cadrul unor anumite practici de semnificare de tip special: epoca socratică, Evul Mediu, capitalismul creat după modelul pieții Agora din Atena. Structura romanului este, în viziunea lui Bahtin, un „,model de lume" ca un sistem specific de semne, a cărui noutate trebuie identificată în contextul istoriei. „Cronotopul reproduce viziunea spațio-temporală și creează compoziția operei literare în imagini convenționale.” (Grati, Corcinschi, 2017, p. 118)

In acest sens, prin studiul de faţă se încearcă explicarea teoriilor și practicilor de construcție identitară a personajelor în raport cu cronotopul literar al orașului Chișinău al anilor '80 din operele românești.

Prezentarea dimensiunii temporale și spațiale ca o cauză a formării identității personajelor o vom realiza în baza operelor Grădina de sticlă de Tatiana Țîbuleac și Înainte să moară Brejnev de Iulian Ciocan.

Astfel, în anii '80 ai secolului trecut, în Basarabia, exista tendința de a „, fetișiza „omul nou" ca produs al noului tip de societate (statul totalitar comunist), omul nou care era de fapt omul gloatei, omul impersonal de la natură și apoi impersonalizat până la capăt printr-o educaţie artificială după tehnica dresajului și a automatizării, așa cum a fost deopotrivă Homo Sovieticus și Homo Moldovanus. Acest om nou mitic urma să fie, ca un șurub în angrenaj, beneficiarul virtualei societăți viitoare finale, adică al societății comuniste care va fi extirpat toate rădăcinile autentice ale tradițiilor spirituale ca să devină societatea ideală fără clase sociale, dar și constructorul acestei societăți utopice.

Homo Moldovanus ideal în varianta sovietică era un individ cu două fețe. Pe de o parte, el trebuia să fie un „simplu om sovietic”, care era automatizat, deindividualizat, opus la tot ce este elitar și original, transparent (adică accesibil pentru un control de ,sus”), modest (primitiv) în cerințe, făcut pentru totdeauna, impasibil la schimbări și ușor de condus. Dar, în același timp, Homo Moldovanus trebuia să fie, de preferință, un antiromân sau, cel puțin, refractar la tot ce e românesc, convins de faptul că este altceva decât român și apărut înaintea românului, puțin educat, vorbitor de limbă „moldovenească”, amestecată cu rusisme, antieuropean și prin extindere antioccidental, predispus spre îndoctrinare, deznaționalizare, rusificare și sovietizare, preferând cu ușurință limba rusă ca mijloc de comunicare în alte circumstanțe decât cele legate de baștina sa, pătruns de un complex de inferioritate față de ruși sau vorbitorii de limbă rusă, complex compensat prin adularea și acceptarea formelor imperiale și culturale de sorginte sovietică, mândru de ideea apartenenței la marea „suprapunere” sovietică. [...] Dar cel 
mai important era faptul că el era mândru de mărețul imperiu în care trăia, iar sentimentul de a fi parte a unei suprapuneri, cu un standard de viaţă relativ bun, în contrast cu cel pe care România l-a avut în epoca comunistă, a creat un mit al superiorității lui Homo Moldovanus Sovietic față de români în perioada Uniunii Sovietice, un mit menit să sublinieze originalitatea acestuia."(Țîcu, 2019, p.12-13)

In acest sens, în romanul Grădina de sticlă de Tatiana Țîbuleac timpul real și imaginar se înlocuiesc repetat și, astfel, se formează un mozaic al Chișinăului. Acțiunea se desfășoară în trecut, dar există și câteva intervenții din timpul prezent imaginar. Vorbind de un discurs sincronic a două etape din viața personajului principal, ambele aflându-se pe scara dramatismului, tragicului, romanul dat are ca repere istorice evenimentele din anii '85-'91 ai secolului trecut și consecințele practicilor de formare a identității Homo Moldovanus Sovietic, (Umărul drept avea o linie adâncă, sângerie, care nu $s$-a vindecat până în ziua în care a venit Gorbaciov) când exista Uniunea Sovietică, când se introduce după ordinul lui Gorbaciov „legea seacă” (alienarea mintală a Tamarei Pavlovna se începe de aici), când oamenii își pierd banii puși la păstrare în bancă, când se introduc cupoanele, când are loc cutremurul din 1986 (Iar noaptea a fost cutremur. Venise din Vrancea, ni s-a spus la televizor. Asta ne făcea România: ne trimetea cutremure.), când are loc explozia de la Cernobâl ( La lecția de limba moldovenească am învățat ce inseamnă radiație și explozie, iar la rusă - герой și долг) și când decadența se face prezentă și simțită, compromițând ideea de renaștere națională, iar războiul din Transnistria este mai mult văzut ca un război care se purta în sinea personajului principal ( Pe mine mă durea în cot de Transnistria și de morții altora. De impușcăturile lor, de eroi, de trădători. Eu eram mortul meu. In mine se purta războiul cel mai crunt).

Cronotopul drumului este unul ilustrativ pentru acest roman, reprezentând o realitate trăită atât fizic, cât și la nivel de conștiință, prin asociere cu chinurile interioare de reconstituire a trecutului și influențele practicilor de deznaționalizare, rusificare, sovietizare . Mixajul timpului și spațiului suferinței/disperării/căutării, omul autorizat, primitiv, impasibil schimbării, ușor de condus se omogenizează în cadrul cronotopului drumului. Dacă am putea face o comparație, în mare parte romanul pare o retrospectivă a drumului interminabil al copilului în devenire a ceea ce înseamnă Homo Moldovanus Sovietic într-o perioadă decadentă, doar că nu are o finalitate, ci doar cicatrici care sângerează și în timpul real imaginar al narării. (drumul de la internat până acasă:...De la gard până acasă mai era o vale. Douăzeci de pași de femeie mare și treizeci și doi de femeie mică. Îi cheltuiam cu mare grijă, fără grabă, mai ales fără grabă. Ca să nu facem stricăciune tocmai atunci.; drumul parcurs zi de zi pentru a aduna sticle: ... Eu mergeam inainte, ca un spărgător de gheață, cu două plase. Ea se târa din urmă, abia-abia, încărcată ca o remorcă. Îmi părea că duc pe umeri un oraș întreg.; drumul 
până la și însuși punctul de colectare a sticlelor: ... m-a împins înăuntru ca într-o groapă. Acolo, în gaura aceea, avea să îmi cheltui cea mai mare parte din copilărie.; drumul educației: Atunci Bella m-a privit lung, mi-a întins o batistă și m-a intrebat moldovenește, așa cum doar ea putea: „Pentru țe trebuie tine limba maldavenească?". I-am răspuns și așa a rămas.; drumul devenirii: Să mă fac doctor-era tot ce-mi rămăsese.).

Discuțiile despre problema identitară a peronajelor apar și în romanul Inainte să moară Brejnev de Iulian Ciocan. În cazul dat ,atestăm măsuri concrete de promovare a unui „moldovenism” politic, axat pe ideea unei separări dintre moldoveni și români. Personajele sunt proiectate și cultivate de autoritățile sovietice în școli și universități, sate și orașe, sovhozuri și colhozuri, uzine și fabrici, într-un cuvânt, RSSM." (Țîcu, 2019, p.13)

Lumea capitalei, parte a Uniunii Sovietice, este derizorie, săracă, supraviețuind de la o zi la alta, iar discursul contradictoriu o dezorientează. Cronotopul romanului este îngrădit de propagandă și lipsă totală de orizont, iar stilul sarcastic de scriere al autorului amplifică imaginea mozaică grotească a orașului (Trecerea anilor - ce semănau perfect unul cu altul - le întărea bănuiala că lucrurile mergeau din ce în ce mai prost. Anul Nou îi găsea mai obosiți, mai bătrâni, mai obsedați de gândul de a strânge bani la ciorap. Munceau din inerție, gârboviți de zădărnicia atotcuprinzătoare. Oricât s-ar fi sforțat, salariile rămâneau aceleași. Numai un miracol le putea schimba din temelie viața în care automatismele se țineau lanț. și blocul de locuințe dădea prea devreme semen de oboseală.; Iulian simți cum se năruie ceva în el. Peste trei zile toate s-au precipitat, timpul a ieșit brusc din hibernare. Toate ziarele anunțau moartea subită a tovarășului Leonid Ilici Brejnev, toate posturile de radio difuzau muzică deprimantă, la școală învățătorii ișsi exprimau doliul prin îmbrăcăminte neagră, discursuri patetice și apostrofări ale elevilor nu prea triști. Mama se dusese la grădiniță îmbrăcată în haine albe, cu gura strident rujată, șocând directoarea și reprezentantul Ministerului Educației. Iulian retrăia scena groaznică a coborârii coșciugului greu în mormânt, gândindu-se că războiul nimicitor poate începe din clipă în clipă.).

Astfel, ,,modelarea unui proiect social și identitar într-un context istoric concret" (Țîcu, 2019, p. 16), când Chișnăul și întreg teritoriul era parte a Uniunii Sovietice, evidențiază o lume literară în care fiecare personaj are mai multe identități genetic asumate sau implantate de mediul în care trăiește.

Din toate cele relatate mai sus observăm că dihotomia identităţii personajelor din proza românească în raport cu „cronotopul culturalistoric"'(Gavrilov, 2018, p. 67) al orașului Chișinău, scoate în evidență o notă insuficientă în abordarea problemei date. Or, doar având un caracter interdisciplinar, transdisciplinar, am putea rezolva ecuația identităţii naționale. Evoluția evenimentelor istorice nu reprezintă un tot întreg al răspunsului. Doar datorită cercetărilor știinţifice: psihologice, sociologice, filozofice etc. am putea determina imaginea identitară din mozaicul urbei. 
Un alt moment important este că personajele din proza românească care ilustrează activitatea în anii '80 sunt deindividualizate, ușor conduse, primitive, transparente, vorbitoare de limbă „moldovenească”, sovietizate și deznaționalizate. Astfel, epoca comunistă a creat mitul supremației lui Homo Moldovanus Sovietic, un mit predispus spre contraziceri continue.

\section{Referințe bibliografice:}

1. GRATI Aliona, CORCINSCHI Nina, Dicționar de teorie literară, Chișinău, Editura ARC, 2017.

2. ȚîCU Octavian, Homo Moldovanus Sovietic, Chișinău, Editura ARC, 2019.

3. GAVRILOV Anatol, PLĂMĂDEALĂ Ion, GRẢTI Aliona, GÎRLEA Olesea, APETRI Dumitru, COGUT Sergiu, ANIȚOI Galina, Relecturi și reinterpretări ale textului literar, Chișinău, Pro Libra, 2018.

4. ȚîBULEAC Tatiana, Grădina de sticlă, Chișinău, Cartier, ediția a IV-a, 2020.

5. Ciocan Iulian, Innainte să moară Brejnev, Iași, Polirom, 2007. 